\title{
Three Cases of Fever Unknown Origin with Lymphoproliferative Features and a Unique Pattern of 18-FDG Uptake on the Fusion PET/CT
}

\author{
Dae Young Yun, Young Hoon Hong, Yong Uk Jung, Myung Jin Oh, Choong Ki Lee \\ Department of Internal Medicine, \\ College of Medicine, Yeungnam University, Daegu, Korea
}

\section{- Abstract-}

Evaluation of a fever of unknown origin (FUO) is complex. Recently, PET scanning has been approved for screening in FUO evaluation. We treated three cases of FUO associated with increased FDG uptake in the bone marrow of the femur and tibia on the fusion $\mathrm{PET} / \mathrm{CT}$; all three had the same pattern of uptake. Bone marrow biopsies revealed mature lymphocyte and histiocyte infiltration and myxoid changes in one case, and cortical bone involvement in another case. The cases were all young females who had fever with neutropenia and relative lymphocytosis that lasted for several weeks and then remitted spontaneously. Even though the results of the studies were not diagnostic, the unique uptake pattern on PET/CT and the histology might be related to the cause of the illness and should be studied further to assess the association with classic FUO.

Key Words: FUO, Bone marrow lymphocytosis, PET

Introduction

Fever of unknown origin (FUO) refers to a condition in which the patient has an elevated temperature for which no explanation has been found despite investigations by a physician. Evolving knowledge and improvements in diagnostic methods necessitate constant updates of the tests included in the minimal diagnostic workup for FUO. Recently, PET scan has been used for FUO evaluation and has revealed novel potential

Correspondence : Choong Ki Lee, Department of Internal Medicine, College of Medicine, Yeungnam University, Daegu, Korea Tel: (053) 620-3841, Fax: (053) 654-8386, E-mail: cklee@med.yu.ac.kr 
diagnostic clues (PDC).

\section{Case 1}

A 28-year-old woman, a married nurse, was admitted to the hospital for intermittent high fevers over the past four months. The patient also had arthralgia in both hands and feet with no swelling or tenderness. Cardiovascular, pulmonary-respiratory, alimentary tract, skin and neurological evaluations were all unremarkable. A fever of up to $39^{\circ} \mathrm{C}$ persisted but was tolerable. The laboratory findings showed a WBC of 2,040 /L, with 46.1\% lymphocytes, $11.9 \mathrm{~g} / \mathrm{dL}$ Hgb, $162 \mathrm{~K} / \mathrm{L}$ platelet, $128 \mathrm{U} / \mathrm{L}$ AST, $107 \mathrm{U} / \mathrm{L}$ ALT, and 11.02/0.62 $\mathrm{mg} / \mathrm{dL} \quad$ BUN/CRE. Urinalysis revealed no hematuria, proteinuria or pyuria.
The chest X-ray showed no active lesions. The blood culture produced no growth. The serologic tests for infection using anti-CMV $\mathrm{Ab}$, anti-EBV Ab, VDRL, anti-HIV, antitoxoplasma $\mathrm{Ab}$ were negative. Autoantibody tests including FANA, ds-DNA IgM, IgG, anti-Smith $\mathrm{Ab}$, anti-Ro, anti-La $\mathrm{Ab}$, and ANCA were all negative. The peripheral blood smear revealed leucopenia with no morphological changes. The TTE showed normal function and dimensions. However, the fusion PET/CT demonstrated increased FDG uptake into the bone marrow of both femurs, patellas, tibias, tarsal bones, metatarsal bones, elbows, wrists, and carpal bones in a symmetric pattern that was consistent with the arthralgia sites (Fig. 1). The MRI revealed marrow infiltration with a high

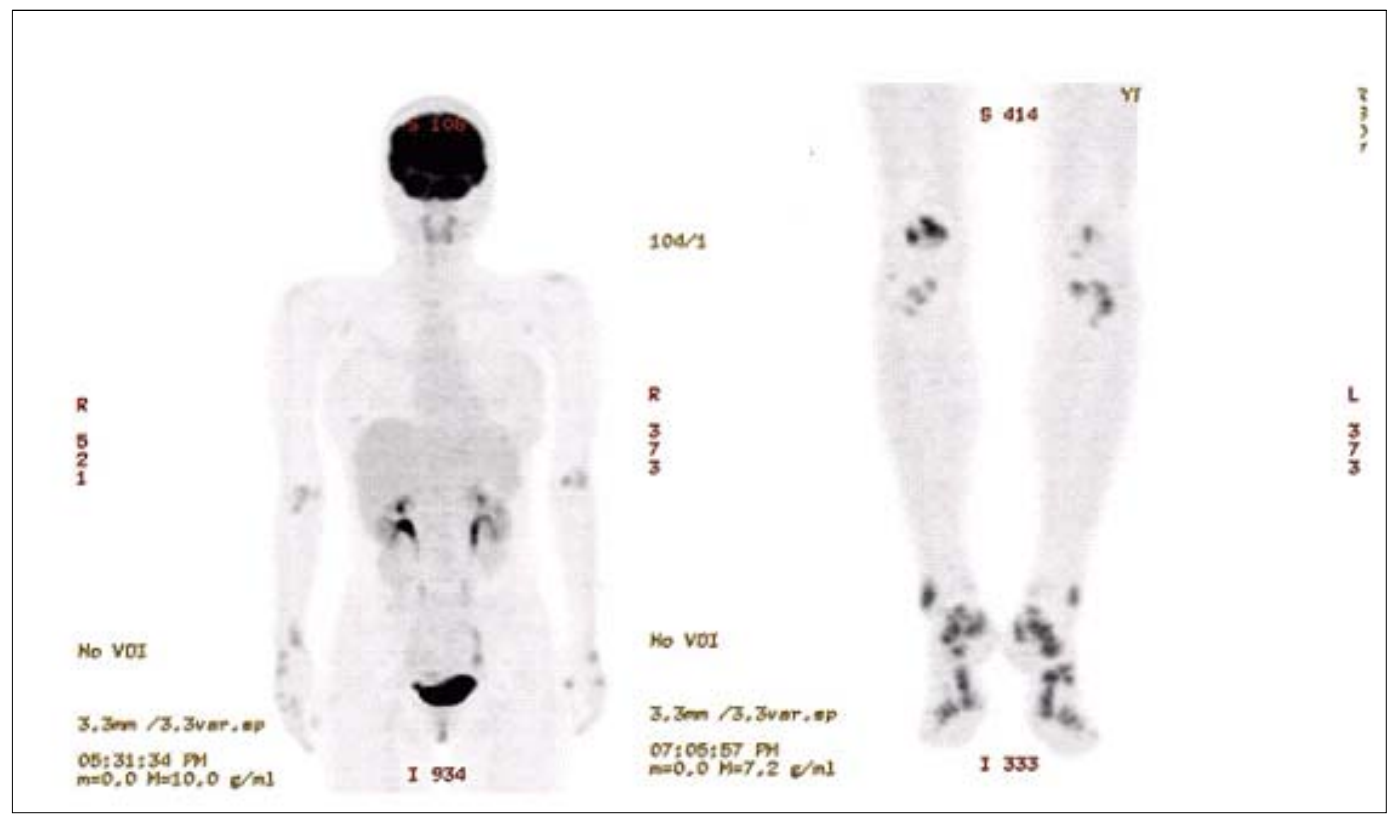

Fig. 1. Fusion PET/CT shows increasing uptake of FDG in areas of both elbow, both wrist, carpal bones, both patella and both feet bones. 
- Dae Young Yun, Young Hoon Hong, Yong Uk Jung, Myung Jin Oh, Choong Ki Lee -

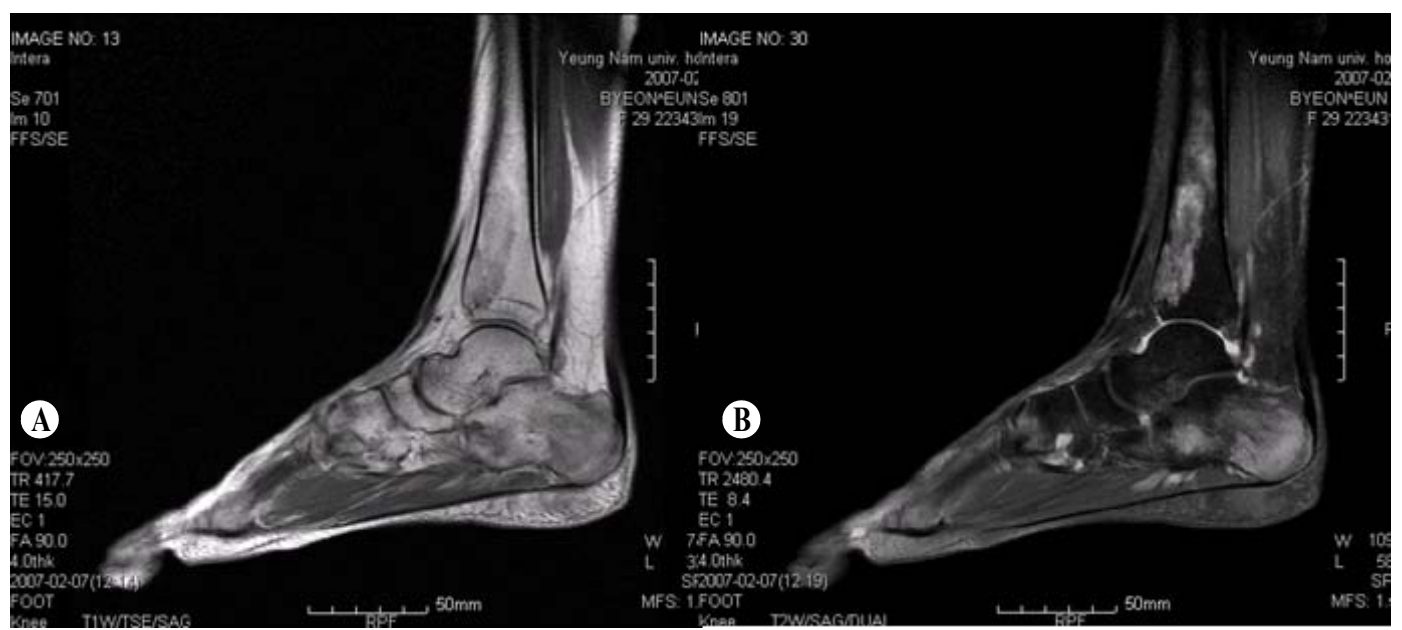

Fig. 2. The MRI shows (A) sagittal T1-weight images demonstrate low signal intensity. (B) sagittal T2-weight fat supression images demonstrate diffuse abnormally increased signal intensity mainly in the calcaneus and distal tibia.

signal on T2 images (Fig. 2). The impression was a systemic disease that infiltrated the bone marrow and included a lymphoma and infection. A surgical biopsy was performed at the left calcaneus; the results demonstrated mature lymphocyte ( $\mathrm{T}$ cell-dominant) and histiocyte infiltration and myxoid changes in the marrow (Fig. 3). After 1 week of hospitalization, the fever subsided spontaneously and the arthralgia resolved.

\section{Case 2}

A 35-year-old homemaker was admitted to the hospital for sustained high fevers lasting 2 weeks and an episode of a febrile

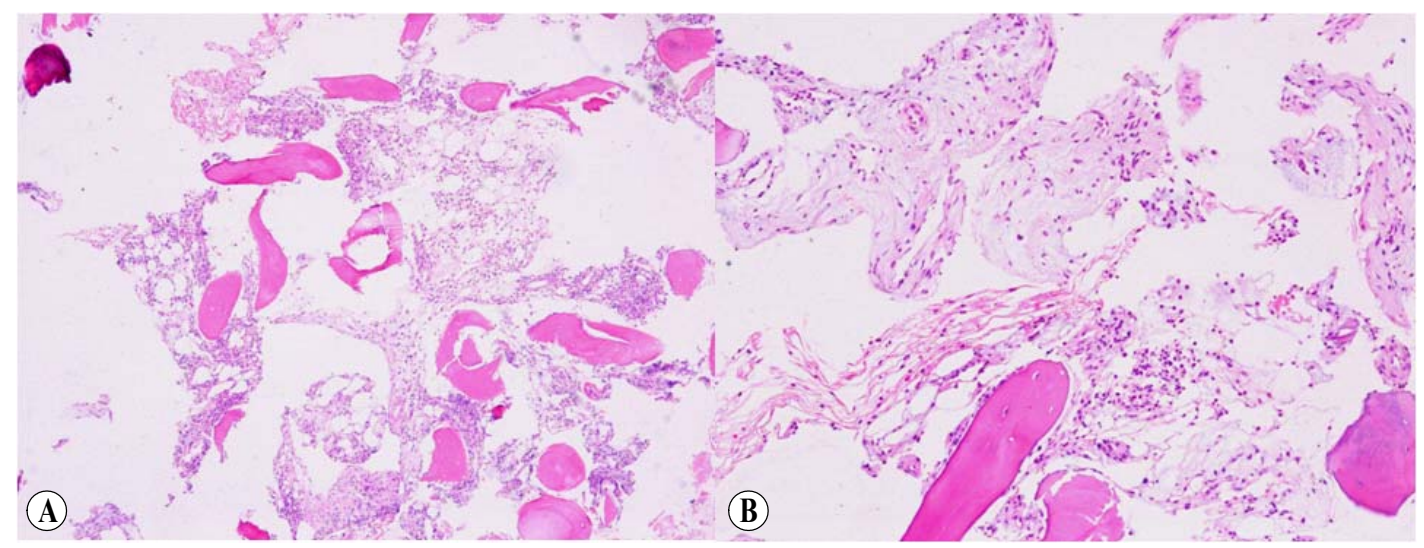

Fig. 3. Left calcaneus biopsy shows lymphocytes(predominantly $\mathrm{T}$ lymphocytes) and histiocyte infiltration(A, Hematoxylin \& eosin, $\times 40$ ). The bone marrow shows myxoid change (B, Hematoxylin \& eosin, $\times 100)$. 


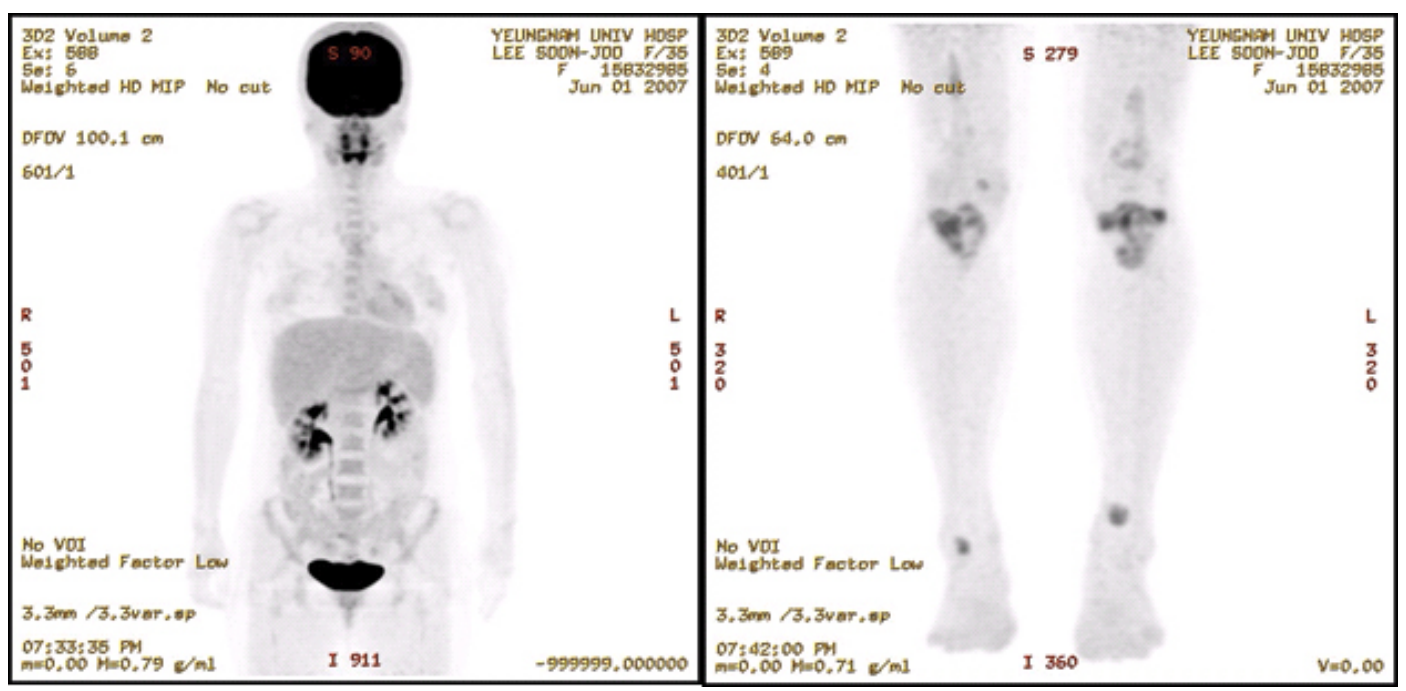

Fig. 4. Fusion PET/CT shows the FDG uptake was localized to femurs, tibias and right taluses and thymus.

illness that had resolved spontaneously 4 months before. The past medical, family and social history were unremarkable, but the patient had a weight loss of about $6 \mathrm{~kg}$ during the past 2 months. The neurological, head and neck, chest and abdominal examinations were within normal limits. The patient complained of spiking fever and chills especially at night. The laboratory findings showed a WBC of 5,740 /L, $11.5 \mathrm{~g} / \mathrm{dL} \mathrm{Hgb}$, $575 \mathrm{~K} / \mathrm{L}$ platelet, $77 \mathrm{~mm} / \mathrm{H}$ ESR, $4.26 \mathrm{mg} / \mathrm{dL}$ CRP, 8.03/0.53 mg/dL BUN/CRE, 20/15 U/L

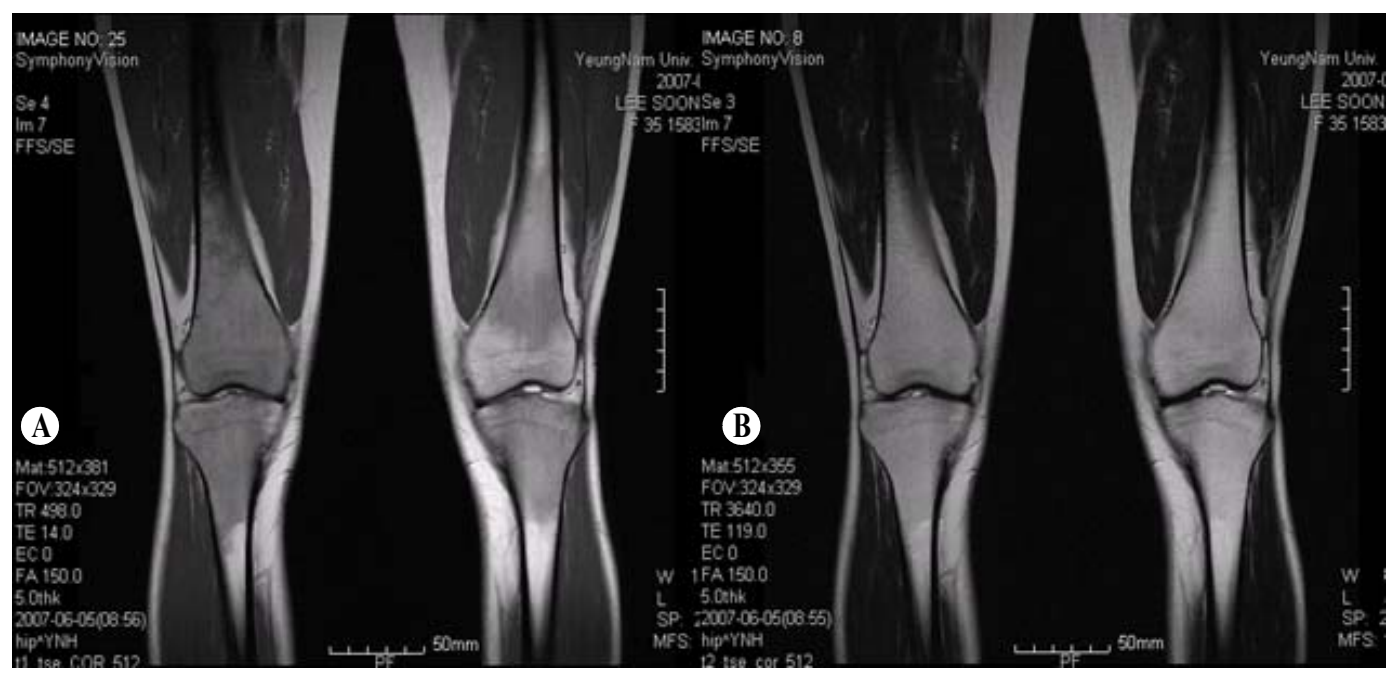

Fig. 5. The MRI shows (A) coronal T1-weight fat supression contrast images demonstrate diffuse loss of normal fat intensity in the distal and proximal tibia and both knees, and the left distal tibia. (B) Coronal T1-weight images demonstrate no specific abnormality. 
- Dae Young Yun, Young Hoon Hong, Yong Uk Jung, Myung Jin Oh, Choong Ki Lee -

AST/ALT, $389 \mathrm{U} / \mathrm{L} \mathrm{LDH}$, and 10.9/39.7 sec PT/APTT. The urinalysis was without hematuria or proteinuria. The peripheral blood smear showed normocytic normochromic anemia without atypical cells. Serologic tests were within normal limits for infection with anti-CMV IgG (+), anti-CMV IgM (-), anti-EBV VCA IgM $(-)$, anti-EBV VCA IgG $(+)$ and EBNA $(+)$, anti-toxoplasma Ab (-), VDRL (-) and HIV Ab (-). In addition, autoimmune disease testing was negative for FANA, ANCA, RF, ASO, ds-DNA Ab, anti-Smith $\mathrm{Ab}$, anti-Ro Ab, and anti-La Ab. The blood culture produced no growth; the serum ferritin was $32.8 \mathrm{ng} / \mathrm{mL}$. The chest radiography, ECG and TTE were unremarkable. A fusion PET/CT was performed and FDG uptake was localized to femurs, tibias, right taluses and thymus (Fig. 4). The MRI signal revealed diffuse loss of normal fat intensity in the distal and proximal tibia and both knees, and in the left distal tibia (Fig. 5). The bone marrow biopsy demonstrated an increase in mature lymphocyte infiltration without distortion (Fig. 6). During the workup, the fever resolved spontaneously.

\section{Case 3}

A 28-year-old woman presented with persistent fever lasting 3 weeks especially at night and newly developed diarrhea and left toe and ankle PIPJs. The patient's history and the examinations were non-specific for a fever focus. Laboratory testing showed a WBC of 4,930 /L, $10.9 \mathrm{~g} / \mathrm{dL} \mathrm{Hgb}, 281 \mathrm{~K} / \mathrm{L}$ platelet, $106 \mathrm{~mm} / \mathrm{H}$ ESR, $6.83 \mathrm{mg} / \mathrm{dL}$ CRP, 9.21/0.63 mg/dL BUN/CRE, 31/48 U/L AST/

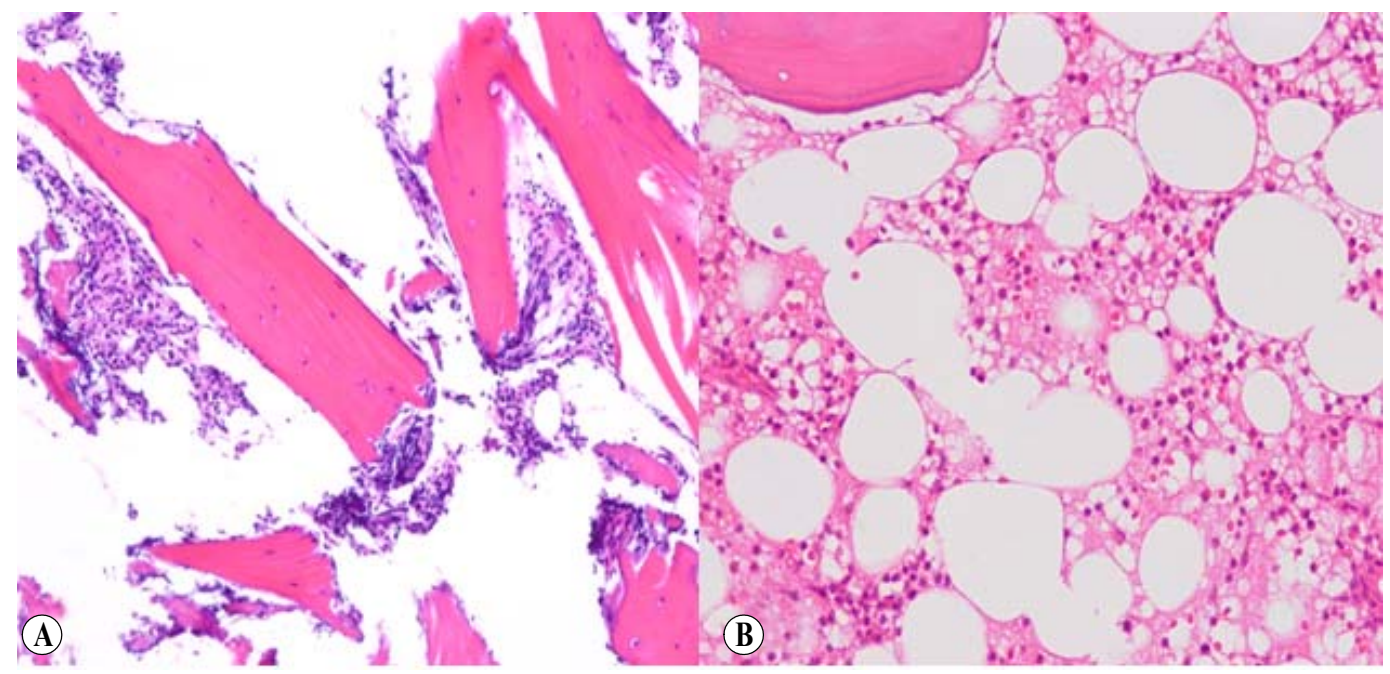

Fig. 6. The left proximal tibia bone biopsy shows fragments of bone and hematopoietic cells (A, Hematoxylin \& eosin stain, $\times 100$ ). Bone marrow showed increased lymphocytic infiltration (B, Hematoxylin \& eosin stain, $\times 200$ ). 
- Three Cases of Fever Unknown Origin with Lymphoproliferative Features and a Unique Pattern of 18-FDG Uptake on the Fusion PET/CT -

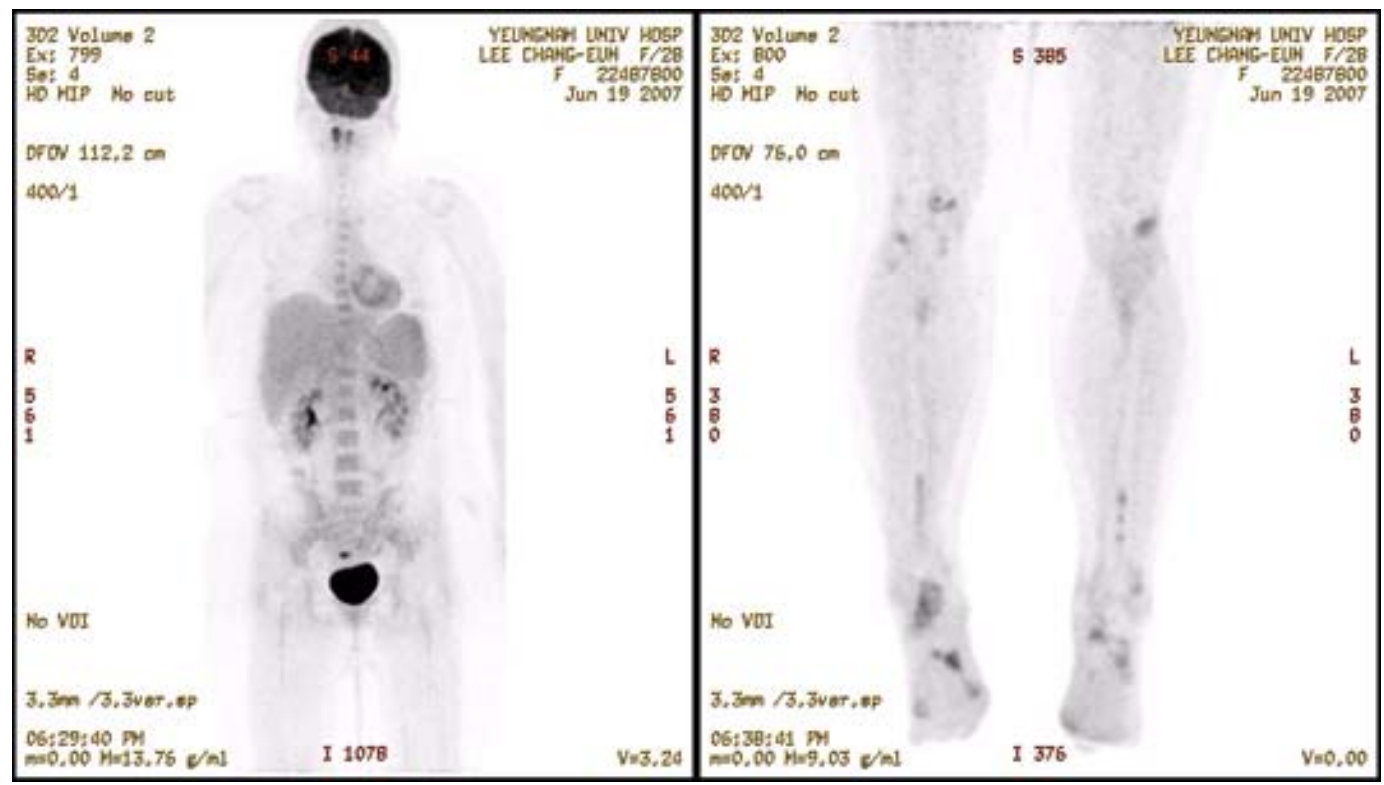

Fig. 7. Fusion PET/CT shows focal FDG uptake in the marrow of the long bones of both lower legs.

ALT, $563 \mathrm{U} / \mathrm{L} \mathrm{LDH}$, and 11.8/36.8 sec PT/ without atypia was noted on the peripheral aPTT. The urinalysis had no hematuria or blood morphology. Serologic testing for proteinuria. A microcytic normochromic anemia infection wasnegative: anti-CMV IgM (-),

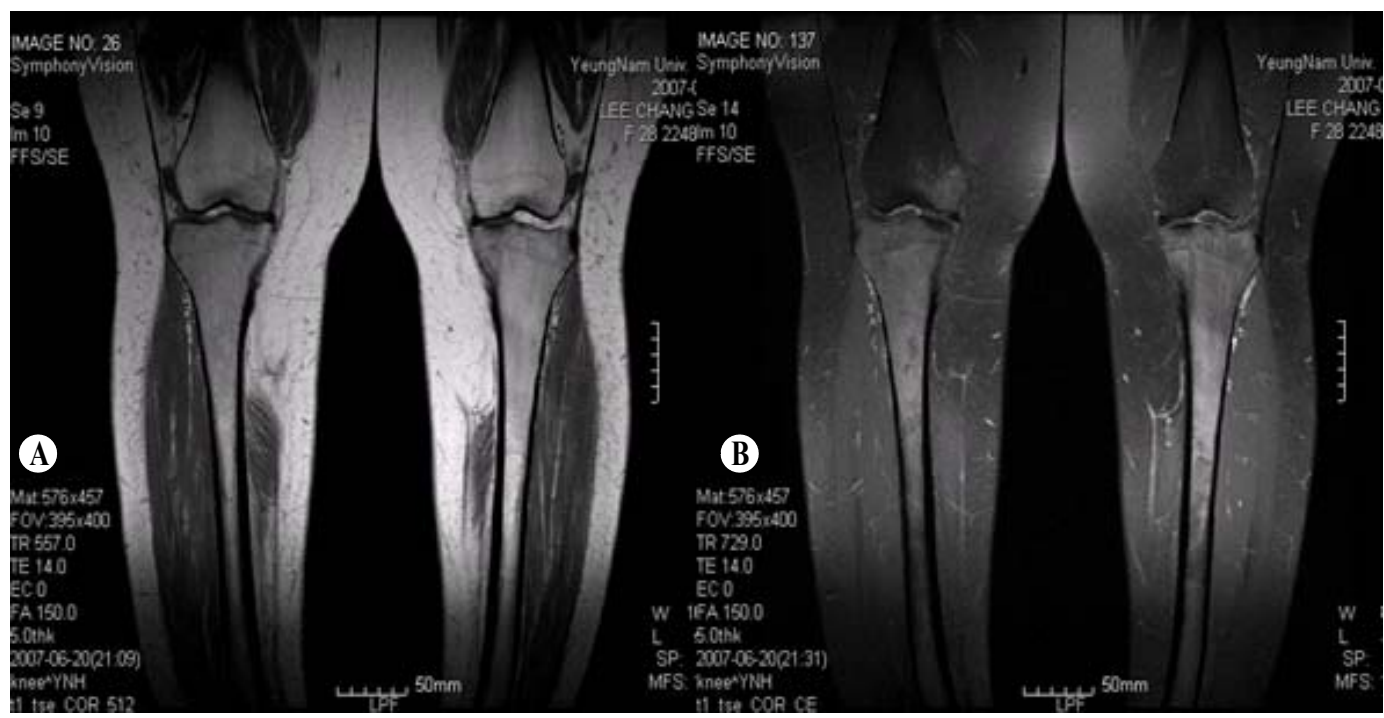

Fig. 8. The MRI shows (A) coronal T1-weight images demonstrate a diffusely low signal intensity in the marrow of both tibias and the right medial femoral condyle. (B)Coronal T1-weight fat supression contrast images demonstrate a diffusely increased signal intensity in the marrow. Coronal T2-weight images demonstrate no specific abnormality. 
- Dae Young Yun, Young Hoon Hong, Yong Uk Jung, Myung Jin Oh, Choong Ki Lee -

anti-CMV IgG $(+)$, anti-EBV IgM $(-)$, antiEBV IgG (+) and EBNA (+), anti-toxoplasma $\mathrm{Ab}(-)$, VDRL $(-)$ and anti-HIV Ab (-). Serologic testing for autoimmune disease was also negative: negative FANA, RF, ASO, ds-DNA Ab, anti-Smith Ab, anti-Ro Ab, and anti-La Ab. The blood culture produced no growth and the serum ferritin was 115.2 $\mathrm{ng} / \mathrm{mL}$. The chest X-ray, ECG and TTE were within normal limits. However, the fusion PET/CT demonstrated focal FDG uptake in the marrow of the long bones ofboth lower legs (Fig. 7). The MRI, used to assess isolated lesions identified on the PET, showed a diffusely increased signal intensity in the marrow of both tibias and the right medial femoral condyle (Fig. 8). The symptoms resolved with conservative therapy without a tissue biopsy and the patient was discharged from the hospital.

\section{Discussion}

Evaluations for FUO are complex and labor-intensive. Repeated history taking, examinations and testing are essential for identification of possible etiologies. ${ }^{1)}$ Even with thorough investigations, about 15 20\% of patients with FUO remain without a specific diagnosis and many cases resolve spontaneously. PET is useful for diagnosing patients with FUO., ${ }^{1,2}$ The findings in this study suggest bone marrow infiltration of lymphocytes, which is typical of lympho- proliferative disorders, such as acute and chronic lymphocytic lymphoma, plasma cell diseases and some infectious diseases, and post-transplantation lymphoproliferative diseases (PTLD). ${ }^{3-6)}$ Previous reports have shown that FDG uptake allows accurate assessment of marrow infiltration and might reduce the need for a staging marrow biopsy in a high proportion of lymphoma patients. ${ }^{1,2)}$ However, there are no reference standards with which to compare the symmetric multiple localized 18-FDG uptake identified in this study in the long bones of patients with FUO. B. Jones et al. suggested that lymphoid aggregates in clinical biopsy material may not be a physiological finding and should alert the pathologist or hematologist to the possibility of a lymphoproliferative disease, in consecutive bone marrow biopsies in patients without known lymphoproliferative disorders. ${ }^{3,4)}$ Even though the results of the laboratory, radiological, PET scan and histology were not sufficient for diagnosis in these cases, some unique findings suggest a common pattern associated with the sustained febrile illness in our three patients with FUO. However, further investigations with a larger patient population are needed to confirm our results.

\section{요 약}

불명열을 규명하기 위한 과정은 여러 복잡 한 검사와 평가를 필요로 하며 새로운 검사법 
의 개발로 그 접근법이 날로 발전하고 새로운 질병 양상이 밝혀지고 있다. 최근에는 $\mathrm{PET}$ 스 켄이 도입되어 불명열의 선별 검사로서 그 효 용성이 높은 것으로 입증되고 있다. 저자들은 전신 fusion $\mathrm{PET} / \mathrm{CT}$ 에서 일정한 양상으로 $\mathrm{FDG}$ 의 섭취가 증가된 불명열 3 례를 경험하고 보고하는 바이다; 3례 모두 대퇴골과 경골에 같은 분포와 양상의 섭취 증가를 보였으며, 골 수 생검상, 2례에서 성숙한 림프구와 조직구의 침윤 및 점액성 변화를 보였고, 그 중 1 예는 겉질뼈도 침범된 소견을 보였다. 환자들은 모 두 수 주간 지속되는 호중구 감소와 상대적 림 프구 증가증이 동반된 열이 있는 젊은 여성이 었고, 자연적으로 완화되었다. 비록 연구 결과 만으로 특정 질환을 분류할 수는 없었지만, 일 련의 특정한 $\mathrm{PET} / \mathrm{CT}$ 양상과 조직 소견은 질 병의 원인과 관련 있을 것이고, 고전적 $\mathrm{FUO}$ 와 관련하여 이러한 새로운 PET FDG 섭취 분포 에 대한 연구가 필요할 것으로 생각된다.

\section{References}

1. Gaeta GB, Fusco FM, Nardiello S. Fever of unknown origin: a systematic review of the literature for 1995-2004. Nucl Med Commun 2006;27:205-11.

2. Carr R, Barrignton SF, Madan B, O’Doherty MJ, Saunders CA, Van der Watt J, et al. Detection of lymphoma in bone marrow by whole body positron emission tomography. Blood 1998;91:3340-6.

3. Hans-Joachim W, Cliona MR, Helen EH. Diagnosis and treatment of posttransplantation lymphoproliferative disease after hematopoietic stem cell transplantation. Biol Blood Marrow Transplant 2002;8:1-8.

4. Ronald SG, Chin-Yang L, Ayalew T, Robert LP. Acquired pure red cell aplasia associated with lymphoproliferative disease of granular $\mathrm{T}$ lymphocytes. Blood 2001;98:483-5.

5. Riley UBG, Crawford S, Barrett SP, Abdalla $\mathrm{SH}$. Detection of mycobacteria in bone marrow biopsy specimens taken to investigate pyrexia of unknown origin. JClin Pathol 1995;48:706-9.

6. Befaulkner-Jones, Howie AJ, Boughton BJ, Franklin IM. Lymphoid aggregates in bone marrow: study of eventual outcome. J Clin Pathol 1988;41:768-75. 